NOTES

\title{
THE TREATMENT OF \\ FOREIGN COUNTRY CONVICTIONS \\ AS PREDICATES FOR \\ SENTENCE ENHANCEMENT \\ UNDER RECIDIVIST STATUTES
}

\begin{abstract}
Alex Glashausser
"I certainly would like Your Honor to put that conviction in quotation marks."

-A defendant's protest against the use of an allegedly unfair prior Mexican conviction to enhance his sentence. $^{1}$

\section{INTRODUCTION}

"[T]he whole purpose of our criminal justice system is to make some effort to prevent people from repeating criminal activity."2 The Missouri trial judge who made this point to a recidivist defendant may have exaggerated, but concern about the amount of crime committed by repeat offenders has recently prompted calls for stricter recidivist statutes. ${ }^{3}$ Every state currently authorizes increased punishment for repeat offenders ${ }^{4}$ under statutes varying in scope,${ }^{5}$ harshness, ${ }^{6}$ and degree of discretion granted to sentencing
\end{abstract}

1. United States v. Moskovits, 784 F. Supp. 183, 185 (E.D. Pa. 1991).

2. Zamorano v. State, 793 S.W.2d 894, 898 (Mo. Ct. App. 1990) (quoting from the trial record).

3. Jane Gross, Drive to Keep Repent Felons in Prison Gains in Californin, N.Y. TIMES, Dec. 26, 1993, at A1.

4. See infra notes $29-31$.

5. For example, some statutes enhance sentences based on previous convictions only for certain offenses. See, e.g., UTAH CODE ANN. \& 76-3-407 (1990) (extending term by three years for each prior conviction when current and prior convictions are for felony sexual offenses); VA. CODE ANN. \& 19.2-297.1 (Michie Supp. 1994) (enhancing sentences 
judges. ${ }^{7}$ Generally, courts apply "habitual offender" laws only when prosecutors choose to invoke them, whereas "three-time loser" statutes ${ }^{8}$ are mandatory in their application. ${ }^{9}$ As the movement to enact tougher crime laws grows, ${ }^{10}$ these laws are likely to become broader and harsher, and more of them may become mandatory in their application.

Many criminals in America have committed crimes in other countries. Such criminals include not only Americans who have broken foreign ${ }^{11}$ laws while traveling abroad but also foreign criminals who have come to the United States. Jan Gramo, for

of defendants convicted of acts of violence if defendants have previous convictions for acts of violence). Other statutes are broader, applying to all felonies, e.g., N.M. STAT. ANN. § 31-18-17 (Michie 1978), or even all offenses, e.g., D.C. CODE ANN. § 22-104 (1989).

6. In Alabama, for example, a defendant with three previous felony convictions of any type must be sentenced to prison for life without parole if convicted of a felony of the most serious grade. ALA. CODE § 13A-5-9(c)(3) (1982). In Alaska, on the other hand, the number of previous felony convictions corresponds to an additional term of years, the number of which is dependent on the base offense. ALASKA STAT. $\$ 12.55 .125$ (1990).

7. Some statutes provide that a sentencing judge may increase a sentence because of prior convictions, e.g., KAN. STAT. ANN. $\$ 21-4504$ (a) (Supp. 1993), while others mandate enhancement, e.g., MD. ANN. CODE art. 27, § 643B (1992).

8. See Gross, supra note 3 , at A1.

9. E.g., WASH. REV. CODE ANN. §§ 9.94A.120(4), .030(25) (West Supp. 1994).

10. Washington state residents recently approved a harsh three-time loser law, WASH. REV. CODE ANN. § 9.94A.120, by a wide margin. Mark Trumbull, Washingtón State: National Lab on Crime, CHRISTIAN SCI. MONITOR, Dec. 17, 1993, at 3. Grassroots efforts to pressure other state legislatures into passing three-time loser laws are gaining momentum, fueled by widely publicized incidents in which experienced criminals have killed helpless victims. For example, in California recently, 18-year-old Kimber Reynolds was killed as she walked out of a restaurant by a criminal with a long record. Gross, supra note 3, at A1. In another California murder, 12-year-old Polly Klaas was abducted from a slumber party and killed by a twice-convicted kidnapper who had been released early from prison after both convictions. Sheryl McCarthy, 3-Strike Law Strikes Out, NEwSDAY, Mar. 7, 1994, at 8; Richard Price, Police Face Criticism in Klaas Death, USA ToDAY, Dec. 7, 1993, at 1A. California governor Pete Wilson has publicly supported life sentences for two-time offenders with respect to violent sex crimes, calling them a "fitting memorial for Polly Klaas." Id.

President Clinton also has expressed support for stricter laws, hoping to send the following message to criminals: "When you commit a third violent crime, you will be put away, and put away for good. Three strikes, and you are out." President Bill Clinton, Address Before a Joint Session of the Congress on the State of the Union (Jan. 25, 1994), 30 WEEKLY COMP. PRES. DoC. 148, 155 (Jan. 31, 1994); see also Violent Crime Control and Law Enforcement Act of 1994, Pub. L. No. 103-322.

11. Throughout this Note, "foreign" means "of or from a country other than the United States." 
example, entered the United States illegally ${ }^{12}$ and embarked on a burglary spree. ${ }^{13}$ Before coming to America, the 55-year-old had twenty-eight felony convictions "from all over the world," including Poland, Germany, and Sweden. ${ }^{14}$ The average criminal may not be as well-traveled as Gramo, but courts should be aware that the criminal records of many defendants are not limited to one country.

The problem of how to treat prior foreign convictions has always existed in states with recidivist statutes that do not directly address the issue, but with increasing "international intercourse,"15 it likely will grow in significance. ${ }^{16}$ Courts have been confronted with the problem since at least 1855, when a judge acknowledged the presence of Canadian fugitives in New York. ${ }^{17}$ Yet no consistent doctrine for analyzing foreign convictions in this context exists. This deficiency may be due to the scarcity of American cases addressing the issue. ${ }^{18}$ The infrequent use prosecutors make of foreign convictions as predicate offenses for recidivist statutes is

12. People v. Gramo, 623 N.E.2d 926, 934 (Ill. App. Ct. 1993).

13. Id. at $929-31$.

14. Id. at 931, 934. An investigator discovered these convictions by using Gramo's fingerprints to get information through the International Criminal Police Organization (Interpol). Id. at 931. The United States has played a more active role in Interpol in recent years, but it has not progressed as far as European countries in developing its international law enforcement relations. Ethan A. Nadelmann, The Role of the United States in the International Enforcement of Criminal Law, 31 HARV. INT'L L.J. 37, $37-38$ (1990).

Gramo's "miserable record" did catch up with him; the court imposed consecutive sentences for his burglary convictions under ILL. ANN. STAT. ch. 730, para. 5/5-8-4(b) (Smith-Hurd 1992), which allows judges to impose consecutive rather than concurrent sentences for defendants whose "history and character" are such that the public requires special protection from them. Gramo, 623 N.E.2d at 934-35. Gramo was not sentenced under a repeat offender statute because the Illinois statute is limited to prior felonies within the state. ILL. ANN. STAT. ch. 730, para. 5/5-5-3(c)(8) (Smith-Hurd Supp. 1994).

15. Branimir M. Janković, PUblic International LAW 115 (1984); see also Tahirih V. Lee \& Joshua Searle-White, Prisoners Dilemma Meets Glasnost: A Comparative Advantage Solution to the United States Prison Crisis, 24 CORNELl INT'L L.J. 25, 25 (1991) ("[T] $]$ he world is growing more interdependent and ... nations function as codependents and are profoundly connected.").

16. See Nadelmann, supra note 14 , at 37 (noting "the growing internationalization of law enforcement").

17. People v. Cæsar, 1 Parker's Crim. Rep. 645, 648 (N.Y. Sup. Ct. 1855). The court observed that the reason the legislature had extended the New York statute enhancing sentences for second offenders to include convictions in foreign countries was the state's proximity to Canada. Id.

18. See A. Kenneth Pye, The Effect of Foreign Criminal Judgments in the United States, 32 UMKC L. REv. 114, 128 (1964). Surprisingly, the number of cases has remained low in the 30 years since Pye commented on their scarcity. 
probably due more to a lack of easy access to foreign criminal records than to prosecutorial discretion. ${ }^{19}$

Concern about the fairness of criminal justice in other countries has caused some reluctance among courts to acknowledge foreign convictions. ${ }^{20}$ Circumspection is laudable when appropriate, but courts should recognize that even convictions under systems without procedural protections mirroring those in the United States often are based on underlying substantive crimes that should be included in the calculus of sentencing repeat offenders, unless otherwise specified by the state legislature. Because the government is not required to prove factors that judges consider when sentencing beyond a reasonable doubt, ${ }^{21}$ courts should be more inclusive in their treatment of foreign convictions. The U.S. Constitution is silent as to what may or should be considered at sentencing. ${ }^{22}$ The U.S. Supreme Court, however, has authorized very broad discretion. ${ }^{23}$ Essentially, sentences should be based on "the fullest information possible concerning the defendant's life and characteristics."24 Surely, foreign convictions constitute relevant information. ${ }^{25}$

Part $I$ of this Note reviews how courts have treated foreign convictions, especially in the context of recidivist statutes. ${ }^{26}$ The

19. See supra note 14 .

20. See, e.g., People v. Braithwaite, 240 N.W.2d 293 (Mich. Ct. App. 1976); infra text accompanying notes $85-88$.

21. McMillan v. Pennsylvania, 477 U.S. 79, 91 (1986).

22. MARK H. MOORE ET AL., DANGERous OFFENDERS 107 (1984). It is unconstitutional, however, to consider a defendant's race, Zant v. Stephens, 462 U.S. 862, 885 (1983), or abstract beliefs, Wisconsin v. Mitchell, 113 S. Ct. 2194, 2200 (1993).

23. See, e.g., Pennsylvania ex rel. Sullivan v. Ashe, 302 U.S. 51, 55 (1937) ("For the determination of sentences, justice generally requires consideration of more than the particular acts by which the crime was committed ....."). The Court appears historically opposed to retribution, at least as a sole rationale, having held that "the punishment should fit the offender and not merely the crime." Williams v. New York, 337 U.S. 241, 247 (1949).

24. Williams, 337 U.S. at 247. For example, the U.S. Court of Appeals for the Second Circuit has held that sentencing judges can consider the results of previous efforts to rehabilitate the defendant. United States v. Bradley, 812 F.2d 774, 781 (2d Cir.), cert. denied, 484 U.S. 832 (1987).

25. The Federal Sentencing Guidelines, which base sentences on various factors particular to the individual and to the crime, including a criminal history "score," exclude foreign convictions from the criminal history score but allow them to justify departures from the range of punishment otherwise dictated. See U.S. SENTENCING COMM'N, GUIDELINES MANUAL \$\$ 4A1.2(h), 4A1.3(a) (1991).

26. Although this Note focuses on repeat offender statutes, the dearth of cases directly on point necessitates the analysis of decisions of both federal and state courts ad- 
treatment of foreign convictions by some state legislatures and the silence of others ${ }^{27}$ also are considered. Part II discusses the policy reasons to count such convictions as predicates for enhanced penalties and stresses that counting foreign convictions results in the equal treatment of defendants whose prior crimes were in the United States and defendants with foreign criminal records. Part III explores the constitutional limits on the use of such convictions.

Part IV proposes a standard for courts to use in evaluating foreign convictions when considering whether they should be included as predicate offenses in prosecutions under repeat offender statutes that do not prohibit such inclusion. It argues that the touchstone should be the reliability of the conviction. That is, courts should evaluate whether the foreign conviction is reliable evidence that the crime underlying the conviction actually occurred. For example, foreign convictions based on forced confessions should be ignored because of the doubt cast on the determination of guilt in such a situation; those based on physical evidence obtained by nieans that would be unconstitutional in the United States, however, should be counted. Currently, defendants whose prior crimes have been confined to the United States are more likely to be sentenced under recidivist statutes than defendants with foreign criminal records, because courts tend not to accord foreign judgments the respect they deserve.

\section{Judicial AND Legislative TREatment OF FOREIGN CONVICTIONS}

\section{A. Interpretations of Statutory Language}

The current ${ }^{28}$ treatment of foreign convictions in repeat of-

dressing the use of foreign convictions for other purposes as well, such as impeaching a witness or justifying a deportation.

27. The Federal Sentencing Guidelines also address this issue. See infra notes 32-33 and accompanying text.

28. In most repeat offender Jaws, the treatment of foreign convictions has not changed recently with regard to what jurisdictions convictions may be from to be counted as predicates for sentence enhancement. Perhaps because of its convenient location as a port of entry into the United States, Florida recently broadened its habitual offender act to encompass prior felony convictions from "the District of Columbia, . . . any possession or territory [of the United States], or any foreign jurisdiction . . . ." Act of July 5, 1989, ch. 89-280, sec. 1, \& 775.084(1)(c), 1989 Fla. Laws ch. 89-280 (codified as amended at FLA. STAT. ANN. \& 775.084(1)(c) (West 1992)). Previously, only convictions from within the United States had been counted. FLA. STAT. ANN. $\$ 775.084(1)(c)$ (West 1987) (amended 1989). 
fender statutes varies widely: eight states explicitly authorize their consideration, ${ }^{29}$ twenty states implicitly disallow it, ${ }^{30}$ and the remaining twenty-two states and the District of Columbia have ambiguously worded statutes. ${ }^{31}$ Under the Federal Sentencing Guidelines, a foreign conviction does not contribute to a defendant's criminal history "score" 32 but may be used as a factor to justify departure from the otherwise mandated range of punishment. ${ }^{33}$

New York, oddly, amended its original repeat offender statute, Act of Apr. 15, 1823 , ch. CLX, \& VI, 1823 N.Y. Laws 179 , to include foreign countries 150 years ago, see People v. Cæasar, 1 Parker's Crim. Rep. 645, 648 (N.Y. Sup. Ct. 1855), only to revert to the ambiguous language "any other jurisdiction" in 1973. Act of May 8, 1973, ch. 277, sec. 9, $\$ 70.06(1)(b)(i), 1973$ N.Y. Laws 1070 (codified as amended at N.Y. PENAL LAW $\S 70.06(1)(b)(i)$ (McKinney 1987)). The holding of People v. LeGrand, 439 N.Y.S.2d 695, 697 (App. Div. 1981), though, shows that this amendment did not affect how courts interpret the statute. See infra notes 59-60 and accompanying text.

29. CAL. Penal Code $\S 668$ (West 1988); Fla. Stat. ANN. $\S 775.084(1)$ (c) (West 1992); KAN. StAT. ANN. \& 21-4504(a) to (c) (Supp. 1993); LA. ReV. Stat. ANN. $\S 15: 529.1$ (A) (West 1992); MinN. STAT. ANN. \& 244 cmt. II.B.501 (West Supp. 1993); OKLA. STAT. ANN. tit. 21, § 54 (West 1983); TENN. CODE ANN. §§ 40-35-106(b)(5), $-107(b)(5),-108(b)(5)$ (1990); VT. STAT. ANN. tit. 13, § 11 (1974).

30. Conn. Gen. Stat. Ann. \& 53a-40(a) (West Supp. 1993); Del. Code Ann. tit. 11, § 4214 (Supp. 1992); GA. CODE ANN. § 17-10-7 (1990); ILl. ANN. STAT. ch. 730, para. 5/5-5-3(c)(8) (Smith-Hurd Supp. 1994); IowA CODE ANN. § 902.8 (West 1994); ME. Rev. Stat. AnN. tit. 17-A, § 362(3-A) (West Supp. 1993); Mass. AnN. Laws ch. 279, $\S 25$ (Law. Co-op. 1992); Miss. CODE ANN. § 99-19-81 (Supp. 1993); NEB. Rev. Stat. $\S 29-2221(1)$ (1989); N.M. STAT. ANN. $\S 31-18-17$ (A) (Michie Supp. 1994); N.C. GEN. STAT. \& 14-7.1 (1986); N.D. CENT. CODE \& 12.1-32-09(1)(c) (Supp. 1993); OHIO REV. CODE ANN. \& 2929.11(B)(1)(b)-(3)(b) (Baldwin 1992); OR. REV. STAT. \& 161.725(3)-(4) (1990); 42 PA. CONS. STAT. ANN. \& 9714(b)(1) (1982); R.I. GEN. LAWS \& 12-19-21(A) (Supp. 1993); S.C. CODE ANN. \& 17-25-45(1)(A) (Law. Co-op. Supp. 1993); S.D. CODIFIED LAWS ANN. \& 22-7-7 (1988); VA. CODE ANN. § 19.2-297.1(B) (Michie Supp. 1994); W. VA. CODE \& 61-11-18 (Supp. 1994).

31. AlA. CODE § 13A-5-9 (1982); ALASKA StAT. § 12.55.145(a)(2) (1989); ARIZ. REv. STAT. ANN. § 13-604(N) (Supp. 1993); ARK. CODE ANN. \& 5-4-503 (Michie 1993); COLO. REV. STAT. \& 16-13-101(1) to (2) (Supp. 1993); D.C. CODE ANN. \& 22-104a(b)(1)(B) (1989); HAW. REV. STAT. \& 706-662 (1994); IDAHO CODE § 19-2514 (1987); IND. CODE ANN. \& 35-50-2-8 (Burns 1994); KY. REV. STAT. ANN. § 532.080(2) (Baldwin 1992); MD. ANN. CODE art. 27, § 643B(c) (1992); MICH. COMP. LAWS ANN. §§ 769.10-.12 (West Supp. 1994); MO. ANN. STAT. § 558.016 (Vernon Supp. 1994); MoNT. CODE ANN. § 46-18-501(1) (1993); Nev. REV. STAT. ANN. § 207.010 (Michie 1992); N.H. REV. STAT. ANN. \& 651:6(I)(c) (1986 \& Supp. 1993); N.J. STAT. ANN. \& 2C:44-4(c) (West 1982); N.Y. PENAL LAW \& 70.06(1)(b)(i) (McKinney 1987); TEX. PENAL CODE ANN. \& 12.42 (West 1994); UTAH CODE ANN. \& 76-3-407 (1990); WASH. REV. CODE ANN. \& 9.94A.030(12)(a) (West Supp. 1994); Wis. STAT. ANN. \& 939.62 (West 1982); WYo. STAT. \& 6-10-201(a)(ii) (1988).

32. UNITED STATES SENTENCING GUIDELINES \& 4A1.2(h) (1991). Under the Guidelines, a defendant's score helps determine the appropriate sentence. Id. $\$ 4 \mathrm{~A}$, introductory commentary.

33. Id. $\$ 4 \mathrm{~A} 1.3(\mathrm{a})$. The discussion immediately following subsection $4 \mathrm{~A} 1.3(\mathrm{e})$ specifi- 
The statutes that do authorize the consideration of foreign convictions use clear language to describe where predicate convictions may originate, such as "any other state, government, country, or jurisdiction,"34 "[any other state or] any foreign jurisdiction,"35 or "[auy other state or] foreign government." utes that appear to leave no room for foreign convictions use language such as "this or any other state." 37 As a result, the courts in states with this type of statute are bound to ignore foreign convictions for the purposes of repeat offender statutes, despite the policy reasons for counting them. ${ }^{38}$

Barring legislative clarification, courts in states with ambiguously worded statutes have the opportunity to support the policy of considering foreign convictions by reading them into the ambit of the statutes. ${ }^{39}$ Ambiguous recidivist statutes use open-ended phrases such as "another jurisdiction," 40 "any other jurisdiction,"

cally mentions, as an example of "when the criminal history category significantly underrepresents the seriousness of the defendant's criminal history," "the case of a defendant who . . . had several previous foreign sentences for serious offenses." Id. $\S 4$ A1.3.

In United States v. Soliman, 889 F.2d 441, 444-45 (2d Cir. 1989), the Second Circuit upheld the propriety of the trial judge's consideration of the defendant's Italian drug conviction and 10 years' experience drug trafficking in Europe when sentencing the defendant to the maximum within the applicable range dictated by the Guidelines. But see United States v. Azeem, 946 F.2d 13, 16-17 (2d Cir. 1991) (excluding defendant's drug activities in Egypt from calculation of sentence).

34. Cal. Penal Code $\S 668$ (West 1988).

35. Fla. STAT. ANN. \& 775.084(1)(c) (West 1992).

36. KAN. Stat. ANN. § 21-4504(a) to (c) (Supp. 1993).

37. E.g., NEB. Rev. STAT. § 29-2221(1) (1989); R.I. GEN. LAWS § 12-19-21(A) (Supp. 1993). "State" can refer to a foreign government, but in the phrase "this or any other state," the reference appears to be to one of the United States. See People v. Kearney, 258 N.Y.S.2d 769, 773 (Sup. Ct. 1965) (acknowledging that although "state" can refer to any government, it usually refers to a sister state); infra text accompanying notes 61-63.

38. See infra Part II.

39. A competing principle of interpretation is that unclear statutes should be construed in favor of the defendant. See State v. Stover, 368 S.E.2d 308, 309 (W. Va. 1988); see also State .v. Wait, 509 P.2d 372, 375 (Wash. Ct. App. 1973) (ruling that statute with purely penal purpose must be strictly construed), cert. denied, 415 U.S. 930 (1974).

40. N.J. Stat. ANN. \& 2C:44-4(c) (West 1982). The Model Penal Code also uses this phrase. MODEL PENAL CODE \& 7.05(1) (1962). One commentator interpreted this language to include foreign jurisdictions. Pye, supra note 18 , at 131 . He may have relied on the first tentative draft of the Code, in which a comment refers to the consideration of convictions "abroad." MODEL PENAL CODE $\& 7.05 \mathrm{cmt}$. 1 (Tentative Draft No. 1, 1953). Although the language in the Code is still the same ("another jurisdiction"), the word "abroad" no longer appears in the comment. MODEL PENAL CODE \& 7.05 cmt. 1 (1962).

41. MONT. CODE ANN. \& 46-18-501(1) (1993). 
trouble interpreting such language as including foreign country jurisdictions, but courts suspicious of foreign criminal law systems ${ }^{43}$ likely would interpret these phrases as merely readable substitutes for language such as "another state, the United States, a territory of the United States or the commonwealth of Puerto Rico,"44 with no substantive difference.

Several legislatures have implicitly deemed ambiguous language not to include foreign convictions. ${ }^{45}$ For example, section 21-4504 of the Kansas Code once provided that a defendant could be sentenced as a second offender after proof of a former conviction "out of the state." ${ }^{\prime 4}$ In 1992, the statute was amended to include convictions under the laws of "another state, the federal government or a foreign government." was intended by the amendment, it must have been to expand the range of convictions that could be used as predicates to sentence enhancement. ${ }^{48}$ In other words, the legislature had read "out of the state" to exclude foreign countries.

Conversely, when the Michigan legislature amended the state's repeat offender statute, it changed a phrase explicitly including foreign convictions ("any other state, government or country") to an ambiguous phrase ("outside this state"). ${ }^{50}$ Because the purpose of the amendment could not have been to clarify the statute, it must have been to exclude foreign country convictions. ${ }^{51}$ One can infer that the legislature deemed that "outside this state"

42. IDAHO CODE § 19-2514 (1987).

43. E.g., People v. Braithwaite, 240 N.W.2d 293 (Mich. Ct. App. 1976); see infra text accompanying notes $85-88$.

44. N.M. Stat. ANN. \& 31-18-17(A)(2)(a) (Michie Supp. 1994).

45. The Minnesota legislature, on the other hand, has interpreted "out-of-state" to include foreign countries in the state's sentencing guidelines. MINN. STAT. ANN. § 244 cmt. II.B.501 (West Supp. 1994); see also Hill v. State, 483 N.W.2d 57, 60-61 (Minn. 1992) (approving the interpretation expressed in the comment to the guidelines).

46. KAN. STAT. ANN. § 21-4504(e) (1988) (amended 1992).

47. KAN. STAT. ANN. \& 21-4504(a) (Supp. 1993).

48. Legislatures sometimes make amendments for clarification without intending substantive change, but the amendment by the Kansas legislature apparently was not cosmetic: the language "out of the state" was left unamended in another subsection of the statute. See id. \& 21-4504(f).

49. MICH. COMP. LAWS ANN. $\$ 769.10$ (West 1968) (amended 1978).

50. Mich. COMP. LAWS ANN. \& 769.10(1) (West Supp. 1994).

51. The rewording might have been a legislative response to People v. Braithwaite, 240 N.W.2d 293 (Mich. Ct. App. 1976). See infra text accompanying note 91. But see supra note 28 (discussing a New York court's interpretation of a similar change in statutory language as not meaningful). 
excludes foreign countries, an interpretation that might seem reasonable to one not looking beyond the bounds of the United States. ${ }^{52}$ The legislature might have assumed that unless specifically directed to do so, an American court would not consider foreign convictions. Rhode Island's legislature was much clearer when it amended the state's repeat offender statute in 1982, removing the words "or country" from "any other state or country." 53

Courts, on the other hand, have for the most part interpreted ambiguous language as including foreign convictions for the purpose of repeat offender statutes, ${ }^{54}$ although they often discount foreign convictions because of concerns about foreign procedural safeguards or the elements of foreign crimes. ${ }^{55}$ In Gwynne $v$. State, ${ }^{56}$ an Alabama court held that the phrase "any felony" ${ }^{57}$ included Canadian convictions. ${ }^{58}$ Similarly, New York courts have read a repeat offender statute encompassing prior felonies from "any other jurisdiction" 59 as including foreign convictions. ${ }^{60}$ Even

52. Actually, even within the United States, there may be a difference between "outside this state" and "any other state," because the latter does not on its face include federal convictions. Regulatory language in some states suggests, however, that even "outside this state" does not include federal jurisdictions. See, e.g., 204 PA. CODE § 303.7(d) (1993) ("out-of-state or Federal").

53. Act of May 18, 1982, ch. 226, secs. 1-2, \& 12-19-21(A), 1982 R.I. Pub. Laws 1100 (codified as amended at R.I. GEN. LAws § 12-19-21(A) (Supp. 1993)).

54. See, e.g., Zamorano v. State, 793 S.W.2d 894, 899 (Mo. Ct. App. 1990) (acknowledging that foreign convictions could be used to enhance sentences under recidivist statute). The Missouri statute does not address the issue of where prior convictions may originate. Mo. ANN. STAT. \& 558.016 (Vernon Supp. 1994).

55. See infra text accompanying notes $98-99$.

56. 499 So. 2d 802, 809 (Ala. Crim. App. 1986).

57. ALA. CODE $\S 13 A-5-9$ (1982). The court interpreted this statute in light of what is now ALA. R. CRIM. P. 26.6(b)(3)(iv), which restates the scope as "[a]ny conviction in any jurisdiction ...."Gwynne, 499 So. $2 \mathrm{~d}$ at 809.

58. The court in Gwynne was influenced by a prior interpretation of the same words: "[The language 'any felony' of $\S 13 A-5-9]$ means that all felonies come within the purview of the habitual offender statute, regardless of their origin." Watson v. State, 392 So. 2d 1274, 1279 (Ala. Crim. App. 1980) (considering a sister-state conviction) (emphasis added), writ denied, 392 So. $2 \mathrm{~d} 1280$ (Ala. 1981); see Gwynne, 499 So. 2d at 809 (citing Watson). This background suggests that without the word "regardless," the court might not have been willing to embrace foreign country convictions within the statute.

59. N.Y. PENal LAW §§ 70.04(1)(b)(i), 70.06(1)(b)(i) (McKinney 1987).

60. See, e.g., People v. LeGrand, 439 N.Y.S.2d 695 (App. Div. 1981) (implicitly acknowledging that a Canadian conviction could be used under the statute although discounting conviction because elements of foreign crime did not constitute a crime in New York). For interpretations of different statutory language in New York, see also People ex rel. LaTraverse v. Jackson, 132 N.Y.S.2d 115, 116 (App. Div. 1954); People ex rel. 
the phrase "any other state" was construed as including foreign countries by the New York court in People v. Kearney. ${ }^{61}$ Admitting that such language usually would refer only to sister states, the court nonetheless reasoned that the word "state" can refer to any government. The court found "no apparent basis for any ... distinction [between sister states and foreign governments] aside from the greater difficulty [in evaluating foreign judgments]."62 Kearney's expansive interpretation of a statute that on its face appeared to exclude foreign convictions has been unparalleled; although the case's value as precedent is limited due to the peculiarity of the statutes that affected repeat offenders in New York at the time, ${ }^{63}$ perhaps judges wishing to recognize foreign convictions despite a lack of explicit statutory authorization will look to Kearney for support.

In immigration cases, courts have been as willing to interpret ambiguous statutes in favor of considering foreign judgments as they have been in cases involving sentencing. ${ }^{64}$ Aliens often are deported when the United States government learns of prior convictions; an alien who "at any time ... has been convicted of a violation of . . . any law or regulation ... relating to a controlled substance" may be deported. ${ }^{65}$ Several cases have addressed the issue of whether such convictions may be foreign. The Second, ${ }^{66}$

Stevens v. Jackson, 125 N.Y.S.2d 905, 909 (App. Div. 1953); People v. Cæsar, 1 Parker's Crim. Rep. 645, 648 (N.Y. Sup. Ct. 1855).

61. 258 N.Y.S.2d 769, 772 (Sup. Ct. 1965).

62. Id. at 773 .

63. In 1965, New York law authorized the consideration of any conviction "under the laws of any other state, government, or country" for the purpose of sentence enhancement. N.Y. PENAL LAW § 1941 (McKinney 1917) (amended 1973). Kearney involved a different statute that prohibited the use of invalid prior judgments "in this state or any other state" to enhance sentences. N.Y. PENAL LAW $\S 1943$ (McKinney 1963) (current version at N.Y. PENAL LAW $\$ 70.06$ (McKinney 1987)). The court noted that especially compared with $\S 1941, \S 1943$ seemed to be restricted to the United States. The court decided, however, that the legislature had not meant what it wrote. Before $\S 1943$ was enacted, defendants sentenced under $\$ 1941$ could challenge prior New York convictions, but the legislative history for $\S 1943$ evinced an effort to provide similar procedures for prior convictions from "another jurisdiction." 1964 N.Y. LEG1S. ANN. 514. Because "invidious discrimination" would result from withholding such protection only from those convicted in foreign countries, the court read beyond the plain language of $\S 1943$ to make it cover foreign countries. Kearney, 258 N.Y.S.2d at 774.

64. E.g., Brice v. Pickett, 515 F.2d 153, 154 (9th Cir. 1975).

65. 8 U.S.C. § 1251(a)(2)(B)(i) (Supp. IV 1992) (emphasis added).

66. Gardos v. INS, 324 F.2d 179, 180 (2d Cir. 1963) (affirming deportation based on marijuana conviction from Canada). 
Fifth, ${ }^{67}$ and Ninth ${ }^{68}$ Circuits have held that "any law or regulation" includes foreign laws or regulations. The danger of analyzing repeat offender cases by comparing them to immigration cases is that courts protect the rights of aliens less than those of citizens ${ }^{69}$ when the language to be interpreted is the same, however, these decisions have some persuasive authority to guide courts in deciphering phrases like "any jurisdiction" in repeat offender laws.

\section{B. Judicial Treatment}

Once statutory language is interpreted as including foreign convictions, the issue of whether legislatures indeed have the power to enhance sentences by counting foreign convictions arises. Most courts faced with this question have given foreign convictions at least preliminary consideration, thereby acknowledging legislatures' power to give effect to foreign judgments. ${ }^{70}$ Other than possible due process concerns stemming from the use of particular foreign convictions, ${ }^{71}$ the issue has been lield not to present a federal question. ${ }^{72}$ New York courts consistently have upheld the authority of the state legislature to increase punishment based on foreign offenses, ${ }^{73}$ despite the lack of primary jurisdiction over such crimes. ${ }^{74}$ Applying New York law, a federal court also acknowledged the legality of counting foreign convictions, finding no reason to distinguish between foreign countries and sister states. ${ }^{75}$

67. Pasquini v. INS, 557 F.2d 536, 538-39 (5th Cir. 1977) (deporting Italian alien because of Bahamian marijuana conviction).

68. Brice, 515 F.2d at 154 (basing deportation on marijuana conviction from Japan and finding that statutory wording "strongly indicates" that Congress intended to include foreign convictions).

69. See Pasquini, 557 F.2d at 539 (noting that deportation laws authorizing the use of foreign convictions do not contemplate subjecting such convictions to American constitutional standards); Brice, 515 F.2d at 154 (holding that aliens may be deported for any reason "in the best interest of the government"); Pye, supra note 18, at 132-33; see also United States v. Verdugo-Urquidez, 494 U.S. 259, 265-67 (1990) (holding that aliens not residing in United States are not protected as much as citizens but not specifying how much connection to the United States is necessary to trigger protection).

70. See infra text accompanying notes 73-82.

71. See infra Part III.

72. United States ex rel. Read v. Martin, 263 F.2d 606, 606-07 (2d Cir. 1959).

73. See, e.g., People v. LeGrand, 439 N.Y.S.2d 695, 697 (App. Div. 1981) (implicitly interpreting the statutory language "any other jurisdiction" to include foreign countries); see also N.Y. PENAL LAW \& 70.04(1)(b)(i) (McKinney 1987).

74. People v. Dacey, 3 N.Y.S.2d 156, 165 (Ct. Gen. Sess. 1938); People v. Cæsar, 1 Parker's Crim. Rep. 645, 648 (N.Y. Sup. Ct. 1855). The Dacey court noted that the question depended only on the policy of the state. Dacey, 3 N.Y.S.2d at 166.

75. United States ex rel. Foreman v. Fay, 184 F. Supp. 535, 537, 539 n.15 (S.D.N.Y. 
Courts in other states have reached similar results. ${ }^{76}$ In Gwynne v. State, ${ }^{77}$ for example, an Alabama court rejected the defendant's contention that his prior Canadian kidnapping offense could not be a predicate for sentence enhancement under the habitual offender statute. ${ }^{78}$ Because it already was settled law that "all felonies come within the purview of the habitual felony offender statute, regardless of their origin," court was whether foreign felonies fell within the ambit of "all." The court held that they did, implicitly acknowledging the power of the legislature to consider foreign convictions. ${ }^{80}$ Similarly, a Washington court held that the principle of comity ${ }^{81}$ dictates that "we give full effect to foreign judgments, except in extraordinary cases." 82

Not all state courts, however, agree on the propriety of using foreign convictions. Michigan courts in particular have been recalcitrant. Different cases have espoused different policies, making the future treatment of foreign convictions in Michigan unclear. ${ }^{83}$ The Michigan legislature also has given mixed signals about how to treat foreign convictions, thereby exacerbating the confusion. ${ }^{84}$

In People v. Braithwaite, the defendant had escaped from a Michigan prison. ${ }^{85}$ During sentencing for the escape, he was

1960).

76. See, e.g., State v. Ralph, 336 So. $2 \mathrm{~d} 836,840$ (La. 1976) (acknowledging that foreign convictions could be used), overniled on other grounds by State v. Berndt, 416 So. 2d 56 (La. 1982); Hill v. State, 483 N.W.2d 57, 61 (Minn. 1992) (finding no valid basis for distinguishing between out-of-country and out-of-state convictions).

77. 499 So. $2 d 802$ (Ala. Crim. App. 1986).

78. See ALA. CODE $\S 13 A-5-9$ (1982). The statute reads in part: "In all cases when ... a criminal defendant has been previously convicted of any felony and after such conviction has committed another felony, he must be punished [more severely.]" Id. $\S 13 \mathrm{~A}-5-9$ (a) (emphasis added).

79. Watson v. State, 392 So. 2d 1274, 1279 (Ala. Crim. App. 1980), writ denied, 392 So. 2d 1280 (Ala. 1981).

80. Gwynne, 499 So. $2 \mathrm{~d}$ at 809.

81. The principle of comity has been defined as "the recognition which one nation allows within its territory to the legislative, executive or judicial acts of another nation, having due regard both to international duty and convenience ...." Hilton v. Guyot, 159 U.S. 113, 164 (1895).

82. State v. Meyer, 613 P.2d 132, 137 (Wash. Ct. App. 1980).

83. Compare People v. Braithwaite, 240 N.W.2d 293 (Mich. Ct. App. 1976) (rejecting foreign convictions) with People v. Wallach, 312 N.W.2d 387 (Mich. Ct. App. 1981) (indirectly rejecting Braithwaite), vacated on other grounds, 331 N.W.2d 730 (Mich. 1983); see also infra text accompanying notes 85-97.

84. See supra text accompanying notes 49-52; infra text accompanying notes 89-91.

85. 240 N.W.2d at 294. 
found to have a previous conviction in Canada. The sentencing judge was greatly influenced by the Canadian conviction in his decision to give the defendant a prison term rather than merely put him on probation. ${ }^{86}$ The appellate court, however, vacated the sentence because of the sentencing judge's reliance on the foreign conviction. In a burst of patriotism, the court boasted that "the constitutional guarantees which our system of justice protects are different in both kind and degree than those recognized even in modern democratic systems such as Canada's." ${ }^{87}$ The court did not even admit to the possibility that another country's system might pass muster, holding that "foreign convictions ... should never be considered by sentencing judges . . .." 88

The holding in Braithwaite is most surprising when viewed in the context of Michigan's repeat offender statute at the time. The statute provided that a defendant with a prior felony conviction "under the laws of any other state, government, or country" should be sentenced as a repeat offender. ${ }^{89}$ The defendant was not sentenced under this statute, so the court was not bound by it. However, this law, which had been in force for nearly fifty years, ${ }^{90}$ manifested a decision by the legislature that foreign convictions should be recognized by Michigan courts. It is odd that the Braithwaite court did not mention this statute when pronouncing its own diametrically opposed view of foreign convictions. Although Braithwaite was not a repeat offender case, the court's attitude showed that if it were presented with an ambiguous repeat offender statute, it would interpret it as excluding foreign convictions. Perhaps swayed by Braithwaite, the Michigan legislature subsequently amended the repeat offender law so that felonies "outside this state" could be used as predicate offenses. ${ }^{91}$ No reported Michigan cases have interpreted whether this ambiguous language includes foreign convictions.

86. See id. The court did not mention the crime underlying the Canadian conviction: because the defendant was not sentenced under the recidivist statute, MICH. COMP. LAWS ANN. \& 769.10 (West 1974) (amended 1978), it may not have been a felony.

87. Braithwaite, 240 N.W.2d at 294.

88. Id. (emphasis added).

89. MICH. COMP. LAWS ANN. § 769.10 (West 1974) (amended 1978).

90. See Act of May 14, 1927, ch. IX, § 11, 1927 Mich. Pub. Acts 324.

91. Act of Mar. 22, 1978, ch. 9, sec. $10 \S 769.10,1978$ Mich. Pub. Acts 206 (codified as amended at MrCH. COMP. LAWs ANN. $\S 769.10$ (West 1994)). No legislative history is available. 
Later Michigan decisions have criticized Braithwaite without overruling it, leaving its present authority unclear. In People v. Wallach, ${ }^{92}$ a defendant convicted of murder challenged the prosecution's use of his prior Canadian conviction to impeach his testimony. The court noted that although Braithwaite did not apply directly because it addressed the sentencing phase, its holding should be considered because a court must be more restrained in using foreign convictions to prove guilt than to decide a sentence. ${ }^{93}$ The court took notice of the Braithwaite court's judgment that convictions from criminal systems different from that in Michigan should be excluded. ${ }^{94}$ The Wallach court then reasoned that such a principle would exclude not only foreign convictions, but sister-state convictions as well. ${ }^{95}$ Considering this result unsatisfactory, the court concluded that "the blanket prohibition of Braithwaite should not be followed." case-by-case analysis of the procedural safeguards in the relevant foreign country. ${ }^{97}$

Even courts that do acknowledge the theoretical validity of using foreign convictions to enhance sentences often strain to find reasons not to count thein. ${ }^{98} \mathrm{~A}$ common escape route is to distinguish the conduct underlying the foreign conviction from conduct that would be a felony in the relevant state. ${ }^{99}$

92. 312 N.W.2d 387 (Mich. Ct. App. 1981), vacated on other grounds, 331 N.W.2d 730 (Mich. 1983).

93. Id. at 403 .

94. Id. at 403 n.8.

95. Id.

96. Id. at 403 .

97. Id. In Wallach, the court held that the Canadian convictions were improperly used for impeachment because the prosecution did not attempt to prove that the Canadian legal system was fundamentally fair. Id. at 404 . People v. Gaines, 341 N.W.2d 519, 521 (Mich. Ct. App. 1983), moved somewhat further away from Braithwaite by holding that when using foreign convictions for impeachment, the prosecution need not prove the existence of procedural safeguards in the foreign country if the defendant does not object. The defendant in Gaines had not objected at trial to the court's consideration of his West German narcotics conviction, so the appellate court affirmed his conviction. Id. at 523-24.

Braithwaite may still be good law, because unlike Wallach and Gaines, it involved sentencing. Furthermore, the dissent in Gaines defended Braithwaite, noting the logistical difficulty of researching the legal systems of countries using foreign languages. Id. at 524 (Maher, J., dissenting).

98. Pye, supra note 18 , at $130-31$.

99. The requirement that the underlying conduct constitute a felony applies to sisterstate convictions as well. But see exceptions cited infra note 196. Almost any comparison 
In State v. O'Day, ${ }^{100}$ the Louisiana Supreme Court's distinction in this regard was particularly tortured. Jack O'Day was convicted of manslaughter and sentenced as a three-time felony offender. One of his previous convictions was in Canada, where he had served a two-year prison sentence for stealing a car; the other conviction was in Oregon. ${ }^{101}$ The state had the burden of proving that these prior offenses amounted to felonies in Louisiana. ${ }^{102}$ Without any discussion, the Louisiana court held that the Oregon conviction was sufficient to justify conviction as a two-time offender. ${ }^{103}$

The court closely scrutinized the Canadian conviction, however, and held that it could not be a predicate for enhancing O'Day's sentence. Under Canadian law at the time of the offense, it was possible to be convicted of "stealing an automobile" without proof of asportation, ${ }^{104}$ an element that the O'Day court held to be essential to the definition of larceny in Louisiana. ${ }^{105}$ Because O'Day "may have done no more than open the car door, get into it, [and] attempt to manipulate the switch and the starter," the

of statutes from different states reveals subtle differences in the conduct proscribed; courts intent on discounting out-of-state convictions usually can do so. Some courts have limited their inquiry to the statutory elements of the other state's crime, while others have further considered the conduct underlying the conviction from the other state in determining whether such a conviction could be used to enhance a sentence. Compare People v. Hickey, 167 Cal. Rptr. 256, 263 (Ct. App. 1980) (rejecting the use of any extrinsic evidence and limiting consideration to the elements of both states' statutes) with People v. Cheri, 179 Cal. Rptr. 423, 425 (Ct. App. 1981) (allowing the examination of any evidence of record to establish whether the conduct underlying the out-of-state conviction would have been a felony in California) (disapproved in People v. Crowson, 660 P.2d 389, 395 n.10 (Cal. 1983)).

100. 185 So. 290 (La. 1938).

101. Id. at 292. The existence of the Canadian conviction was proved by certificates from the Canadian penitentiary and the vice consul of the United States in Canada, but the court did not mention how the Louisiana government obtained this information. Id. at 298. The lack of an efficient system for gaining access to such information may be a reason for the paucity of sentence enhancement cases concerning prior foreign convictions. The convenience of obtaining evidence from foreign countries has increased dramatically, however, through the signing of various mutual legal assistance treaties. Prosecutors therefore should not have as much difficulty investigating the conduct underlying foreign convictions in the future. Nadelmann, supra note 14, at 37-38, 57-58.

102. O'Day, 185 So. at 294.

103. Id. at 299.

104. "The removal of things from one place to another." BLACK's LAW DictionARY 114 (6th ed. 1990).

105. O'Day, 185 So. at 293 (citing Criminal Code, R.S.C. ch. 36, § 347 (1927) (Can.)). 
court ignored the Canadian crime in sentencing him for the Louisiana manslaughter. ${ }^{106}$

Although it is within the Louisiana legislature's power to require that a predicate felony constitute a felony in Louisiana, ${ }^{107}$ the policy goal behind weeding out foreign convictions so vigorously is questionable. ${ }^{108}$ In $O^{\prime}$ Day, the state made no showing as to the facts underlying the Canadian conviction. The prosecution of O'Day in Canada and the two-year jail sentence there, however, suggest that he probably did steal the car, asportation and all; it is unlikely that O'Day would have been prosecuted so vigorously if all he had done was get in the car. ${ }^{109}$ According to the U.S. Supreme Court, sentences are supposed to be based on "the fullest information possible concerning the defendant's life and characteristics," 110 and this information need not be proved beyond a reasonable doubt. ${ }^{111}$ Surely, a conviction for stealing a car was relevant information about O'Day's "life and characteristics." Even if his conduct conceivably would not have constituted a felony in Louisiana, it was not the sort of foreign crime that American courts should ignore on constitutional grounds, such as speech critical of a government.

If the state had proved that the underlying conduct of the Canadian conviction would have been a felony in Louisiana, the O'Day court would have counted the Canadian conviction. Even though all the elements of the Louisiana crime were not covered by the Canadian statute, ${ }^{112}$ the legislative prohibition against enhancing sentences based on out-of-state conduct not proscribed in Louisiana would not have been relevant. In contrast, the New York court in People ex rel. Stevens v. Jackson ${ }^{113}$ foreclosed any possibility of using a Canadian conviction when the Canadian statute differed from the analogous New York statute, regardless

106. Id. at 294 (emphasis added).

107. See LA. REV. STAT. ANN. \& 15:529.1(A) (West 1992).

108. For further discussion of the policy reasons to use foreign convictions, see infra Part II.

109. Prosecutors have wide discretion in Canada. Brian A. Grosman, The Role of the Prosecutor in Canada, 18 AM. J. CoMP. L. 498, 502-03 (1970).

110. Williams v. New York, 337 U.S. 241, 247 (1949).

111. McMillan v. Pennsylvania, 477 U.S. 79, 91 (1986).

112. State v. O'Day, 185 So. 290,294 (La. 1938). The court did not indicate what level of proof by the state would have been necessary.

113. 125 N.Y.S.2d 905 (App. Div. 1953). 
of any proof as to the conduct actually underlying the foreign conviction.

The defendant in Stevens was convicted and sentenced as a four-time offender based in part on a prior Canadian conviction for breaking into a home and stealing a ring and other items. ${ }^{114}$ Satisfied that this offense was equivalent to burglary in New York, the trial court counted the foreign conviction. ${ }^{115}$ The appellate court, however, closely compared the two relevant statutes and held that because intent was part of the New York statute but was not mentioned in the Canadian statute, ${ }^{116}$ the conviction could not be used. ${ }^{117}$ The court recognized that the defendant not only stole but also probably intended to do so. ${ }^{118}$ Nevertheless, the court focused only on the statutory language. Because intent was not an element of the crime for which the defendant was convicted in Canada, the offense could not be counted. ${ }^{119}$

Courts considering foreign convictions outside the realm of recidivist statutes have not analyzed the elements of underlying offenses as closely. In McElvy $v$. Civiletti, ${ }^{120}$ for example, a federal court considered foreign convictions in the context of an extradition treaty between the United States and the United Kingdom. ${ }^{121}$ One of the requirements for extradition from the United States under the treaty is that the offense committed by the fugi-

114. Id. at 908-09.

115. Id. at 908 .

116. The New York statute provided: "A person who ... [w]ith intent to commit a crime therein, breaks and enters a building ... [i]s guilty of burglary . . ." N.Y. PENAL LAW § 404 (McKinney 1944) (current version at $\S 8140.20, .25$ (McKinney 1987)). The Canadian counterpart provided: "Every one is guilty of an indictable offence ... . who ... breaks and enters any dwelling-house by day and commits any indictable offence therein ...." TREMEEAR's ANNOTATED CRIM1NAL CODE $\S 458$ (5th ed. 1944) (current version at Criminal Code, R.S.C. ch. 46, § 348 (1985) (Can.)).

117. Stevens, 125 N.Y.S.2d at 909.

118. Id. at 908 .

119. Id. at 909; see also People v. LeGrand, 439 N.Y.S.2d 695, 696-97 (App. Div. 1981) (holding that previous Canadian convictions for assault and fraud could not be used to sentence defendant as a repeat offender because of the statutory definitions of those crimes in Canada). But see People ex rel. LaTraverse v. Jackson, 132 N.Y.S.2d 115, 116 (App. Div. 1954) (presuming that the intent requisite to make a Canadian conviction for breaking and entering equivalent to the New York felony of breaking and entering was present, even though the certificate of conviction obtained from the Canadian government did not mention intent, because the relevant Canadian statute required intent).

120. 523 F. Supp. 42, 43 (S.D. Fla. 1981).

121. Extradition Treaty, June 8, 1972-Oct. 21, 1976, U.S.-U.K., 28 U.S.T. 227. 
tive constitute a felony under United States law. ${ }^{122}$ The petitioners in McElvy were convicted of marijuana possession in the Turks and Caicos Islands. ${ }^{123}$ The law under which they were convicted did not establish a minimum amount of marijuana necessary to constitute possession, so in theory the petitioners might have been convicted despite possessing only a minute quantity. They argued that the only analogous United States law was 21 U.S.C. § 844(a), which proscribes the possession of even small amounts of marijuana but classifies the crime as only a misdemeanor. ${ }^{124}$ Under the strict analysis of Stevens, the petitioners would have been correct in arguing that their foreign convictions could not constitute felonies under United States law. The McElvy court, however, considered evidence surrounding the Turks and Caicos convictions that suggested that the petitioners had been in possession of vast amounts of marijuana and concluded that the petitioners had engaged in activities that would be classified as felonies in the United States. ${ }^{125}$

The court acknowledged the "theoretical possibility" that the prior conviction was not equivalent to a felony in the United States ${ }^{126}$ but noted that the evidence also allowed the inference that the petitioners intended to distribute the marijuana, which raised the level of crime to a felony. ${ }^{127}$ If the Stevens court had used a similar flexible analysis, it would have recognized the defendant's burglary conviction from Canada. Notwithstanding the different contexts of McElvy and Stevens, the issue in each was essentially the same: whether the conduct underlying a foreign conviction constituted a felony in the United States. ${ }^{128}$ Without

122. Id. at 229-30.

123. The Islands are a British possession.

124. 21 U.S.C. $\$ 844$ (a) (Supp. V 1993); see also 18 U.S.C. $\S 3559$ (a) (1988) (classifying crimes punishable by a prison term of one year or less as misdemeanors).

125. McElvy v. Civiletti, 523 F. Supp. 42,49 (S.D. Fla. 1981).

126. Id.

127. Id. at 49 n.2; see 21 U.S.C. $\$ 841(\mathrm{a})(1)(1988)$.

128. In $M c E l v y$, the language interpreted was that of the treaty: "Extradition shall be granted ... [if] the offense constitutes a felony under the law of the United States of America." McElvy, 523 F. Supp. at 47 (quoting Extradition Treaty, supra note 121, at 229-30). In Stevens, the language at issue was from the New York repeat offender statute: "A person, who, after having been convicted ... under the laws of any other state, government, or country, of a crime which, if committed within this state, would be a felony, ... is punishable [as a repeat offender]." N.Y. PENAL LAw §.1941 (McKinney 1917) (current version at $\S 70.10$ (McKinney 1987)). 
clear standards for evaluating the vahidity of such convictions, the results of future cases will continue to vary among courts.

\section{Policy Reasons to CONSIDER Foreign CONVICTIONS}

The legislatures that have not yet done so should explicitly include foreign convictions in their recidivist statutes as potential predicates for sentence enhancement. Similarly, courts faced with statutes that are unclear in their scope should interpret them broadly to include foreign convictions. ${ }^{129}$ This policy would both further the underlying goals of criminal punishment and protect against unequal treatment of offenders. ${ }^{130}$

One approach to the issue of how foreign convictions should be treated is to examine the theoretical bases of criminal punishment and assess whether the consideration of foreign convictions advances appropriate goals. ${ }^{131}$ A survey of the perceived purposes of punishment and the specific goals of repeat offender

The attitude of the McElvy court toward recognizing foreign convictions was fundamentally different from that of the Stevens court: "This court certainly does not hold that a foreign conviction must contain all the elements of an analogous offense in this country ...." McElvy, 523 F. Supp. at 49 n.2 (emphasis added).

129. This inclusion should still be subject to an analysis of the fairness of the foreign conviction. See infra Part III.

130. If possible, American states should address this issue with one voice, so that other countries know what effect their judgments will have here. See Baker v. Carr, 369 U.S. 186, 211 (1962) (acknowledging that "single-voiced statement[s] of the Government's views" are often desirable but not relinquishing the power of courts to address questions concerning foreign relations); Republic of Iraq v. First Nat'l City Bank, 353 F.2d 47, 50 (2d Cir. 1965) ("It is fundamental to our constitutional scheme that in dealing with other nations the country must speak with a united voice."), cert. denied, 382 U.S. 1027 (1966). The D.C. Circuit has noted that matters "interwoven with . . . policies in regard to the conduct of foreign relations [are] entrusted to the political branches of government as to be largely immune from judicial inquiry." Holmes v. Laird, 459 F.2d 1211, 1215 (D.C. Cir.) (quoting Harisiades v. Shaughnessy, 342 U.S. 580, 588-89 (1952)), cert. denied, 409 U.S. 869 (1972). The judicial and executive branches of the federal government sometimes clash over the intersection of criminal justice and foreign policy. Nadelmann, supra note 14 , at 43 . State legislatures should make clear decisions about respecting foreign judgments so that courts confronted with ambiguous statutes are not pressured by the executive branch, which may have concerns about the foreign policy implications of counting foreign convictions. The fight against crime is universal, and matters of jurisdiction should not stop countries from helping each other execute penal laws to the fullest, 1 M. Cherif Bassiouni \& Ved P. Nanda, International Criminal Law \& 1.9, at 475 (1973); interest in the administration of criminal justice is common to "all peoples of the modern world." $1 \mathrm{id}$. at 476 (quoting Manley O. Hudson, The Proposed International Criminal Court, 32 AM. J. INT'L L. 549, 553 (1938)).

131. It is widely thought that the moral philosophy underlying punishment should guide policy. See David GARLAND, PUNISHMENT AND MODERN SOCIETY 9 (1990). 
statutes reveals that the inclusion of foreign convictions advances these goals whereas exclusion hinders them.

Historically, the principal theories of punishment have been rehabilitation, deterrence, and retribution. ${ }^{132}$ Until the 1970 s, the prevailing attitude in the United States was that punishment should rehabilitate criminals. This idea appealed both to liberals, who approved of the attention given to the individual offender, and to conservatives, who perceived the community as being protected by keeping incorrigible criminals in prison longer than people who could easily mend their ways. ${ }^{133}$ Deterrence also was emphasized as a goal of punishment; the focus on future criminality and the behavioral analysis involved in determining what punishments to mete out were seen as progressive. ${ }^{134}$ Retribution, by contrast, was regarded as an "irrational vestige of benighted times"135 because its moral arrogance ${ }^{136}$ made it appear unprogressive ${ }^{137}$ and backward-looking. ${ }^{138}$

The recent trend, however, has been to downplay rehabilitation and deterrence while emphasizing the goal of retribution. ${ }^{139}$ According to many observers, rehabilitation has been "thoroughly

132. Norman A. Carlson, The Future of Prisons, TRIAL, Mar. 1976, at 27.

133. Andrew von Hirsch, Recent Trends in American Criminal Sentencing Theory, 42 MD. L. REV. 6, 7-9 (1983); see also Robert Fishman, An Evaluation of Criminal Recidivism in Projects Providing Rehabilitation and Diversion Services in New York City, $68 \mathrm{~J}$. CRIM. L. \& CRIMINOLOGY 283, 299 (1977) (showing the failure of rehabilitation through empirical data).

134. IgOR PRIMORATZ, JustifyIng Legal Punishment 9-11 (1989).

135. David Dolinko, Three Mistakes of Retributivism, 39 UCLA L. REV. 1623, 1623 (1992); see also Carlson, supra note 132, at 29 (noting the "humaneness" of rehabilitation).

136. Philosophers associated with advocating retributivism to express moral outrage include Immanuel Kant and Emile Durkheim. See, e.g., IMMANUEL Kant, CRITIQUE OF Practical Reason 39 (Lewis W. Beck trans., 1956); EMILe DURKheim, THe Division OF LABOR IN SOCIETY 108 (George Simpson trans., 1965). But cf. CESARE BECCARIA, ON CRIMES AND PUNishments 13 (Henry Paolucci trans., 1963) ("Punishments that exceed what is necessary for protection of the [public] are by their very nature unjust ....").

137. Von Hirsch, supra note 133 , at 8 .

138. Ernest W. Schoellkopff, Comment, Ordering the Purposes of Sentencing: A Prologue to Guidelines, 2 NOTRE DAME J.L. ETHICS \& PUB. POL'Y 503, 518 (1986).

139. Ralph D. Ellis \& Carol S. Ellis, Theories of Criminal Justice 55 (1989). 
discredited as a basic justification for criminal punishment,"140 and retribution is the new ideal. ${ }^{141}$

Many state courts have articulated the policies underlying repeat offender statutes. ${ }^{142}$ Retribution is the philosophy cited most often, although deterrence ${ }^{143}$ and rehabilitation ${ }^{144}$ also have been mentioned as rationales. The Rhode Island Supreme Court, for example, commenting on the state's habitual offender statute, ${ }^{145}$ observed that " $[t]$ he statute reflects the Legislature's determination that a third or subsequent offense is more serious than a first or second offense and accordingly should be punishable as such." ${ }^{146}$ Similarly, Washington's recidivist statute ${ }^{147}$ has been characterized as "purely penal." 148

140. Schoellkopff, supra note 138 , at 503. Empirical studies showing the ineffectiveness of rehabilitation brought about its downfall as a penological ideal. See, e.g., STEPHEN R. BRODY, THE EFFECTIVENESS OF SENTENCING 5 (1976). Concern about inequalities resulting from disparities in sentencing among like offenders also contributed to the decline of rehabilitation. Von Hirsch, supra note 133, at 12-13. Defenders of the theory now have been reduced to arguing that one can still "hope" that prison will reform offenders. MOORE ET AL., supra note 22, at 23.

141. See, e.g., Dolinko, supra note 135 , at 1623 . The current popularity of determinate sentencing has been based on retributivism. Schoellkopff, supra note 138, at 517-18. The Sentencing Reform Act of 1984 officially recognizes retribution, deterrence, incapacitation, and rehabilitation as sentencing goals, 18 U.S.C. \& 3553(a)(2) (1988), but retribution has been called the principal philosophy behind the Federal Sentencing Guidelines. Schoellkopff, supra note 138, at 504, 518.

A change in the language of an authoritative hornbook is a telling indicator of retributivism's ascent. The second edition of LaFave \& Scott's Criminal Law, WAYNE R. LAFAVE \&. AUSTIN W. SCOTT, JR., CRIMINAL LAW 25 (2d ed. 1986) [hereinafter LAFAVE \& SCOTT (2d ed.)], omitted the following emphasized language that was included in the first edition: "[Retribution] is the oldest theory of punishment, and the one which is least accepted today by theorists ...." WAYNE R. LAFAVE \& AUSTIN W. SCOTT, JR., HANDbOOK ON CRIMINAL LAW 24 (1972) (emphasis added); see Dolinko, supra note 135, at $1623 \mathrm{n} .2$ (noting this alteration).

142. The U.S. Supreme Court also has commented on the policies behind recidivist statutes, characterizing their purposes as deterrence and incapacitation. Rummel v. Estelle, 445 U.S. 263, 284 (1980).

143. See, e.g., State v. Conley, 222 N.W.2d 501, 503 (Iowa 1974) ("Recidivist statutes are enacted in an effort to deter and punish incorrigible offenders.").

144. See, e.g., Rezin v. State, 596 P.2d 226, 227 (Nev. 1979) ("By enacting the habitual criminal statute, the legislature sought ... to afford [repeat offenders] an opportunity to reform.").

145. R.I. GEN. LAWS § 12-19-21 (1981) (amended 1988).

146. State v. Tregaskis, 540 A.2d 1022, 1026 (R.I. 1988).

147. WASH. REV. CODE ANN. $\$ 9.92 .090$ (West 1971) (amended 1992).

148. State v. Wait, 509 P.2d 372, 375 (Wash. Ct. App. 1973), cert. denied, 415 U.S. 930 (1974); see also People v. Sunday, 455 N.W.2d 321, 322 (Mich. Ct. App. 1990) (noting that the purpose of Michigan's recidivist statute, Mich. COMP. LAWS ANN. $\$ \S 769.10-12$ (West Supp. 1994), is to punish "indifference to the law"). 
Even under the outmoded doctrine of rehabilitation, the use of foreign convictions as predicates for repeat offender statutes would be warranted. One who violates laws in another country ${ }^{149}$ is just as dangerous in the future as one who violates laws in the United States and is therefore equally in need of rehabilitation. A rehabilitationist might argue that a foreign crime, even if its underlying conduct was such that it could be proscribed by an American legislature without constitutional problems, is the product of a foreign society and that therefore a foreign crime is not an indicator of a defendant's need for rehabilitation. Even if one presumed a defendant's foreign conviction to be the product of a foreign society, though, such a presumption should be negated by the first commission of a felony in the United States. ${ }^{150}$

A deterrence rationale, in contrast, somewhat minimizes the need to consider foreign convictions. Criminals in the United States with foreign criminal records might be deterred by recidivist statutes that count foreign convictions; neither the entry into the United States of people with foreign criminal records nor the rate of crime abroad by people who plan to come to the United States, however, likely would be affected. Still, potential foreign criminals should be able to know whether United States courts will take notice of their foreign convictions so that they can rely on the law. ${ }^{151}$

149. Foreign convictions under laws that would be unconstitutional in the United States are exceptions. See infra text accompanying note 202.

150. Most foreigners who enter the United States do not commit felonies here. See

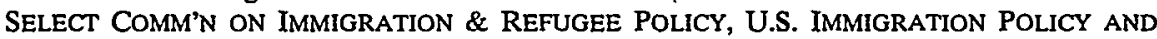
THE NATIONAL INTEREST: STAFF REPORT OF THE SELECT COMMISSION ON IMMIGRATION AND REFUgeE POLICY TO THE CONGRESS AND PRESIDENT OF THE UNITED STATES 181 (1981). If a defendant with a criminal record in another country does commit a felony here, it is more likely than not that the defendant's criminality is less superficial or ephemeral, and that therefore the amount of behavioral conditioning (i.e., imprisonment) necessary to rehabilitate the defendant is greater, than in the case of a recidivist with a record confined to the United States. Under a rehabilitative system, therefore, the foreign crimes should be considered at sentencing. Although foreign crimes may be merely a product of a foreign society, the reasonable doubt standard does not apply at the sentencing phase, McMillan v. Pennsylvania, 477 U.S. 79, 91 (1986); by the preponderance of evidence, foreign crimes do shed light on a defendant's character. See infra notes $159-60$ and accompanying text.

151. According to the principle of legality, people may not be punished for conduct unless they had the opportunity to know that the conduct was proscribed. LAFAVE \& SCOTT (2d ed.), supra note 141, at 195. 
Retribution, however, has become the prevailing theory of punishment, not only in a broad sense ${ }^{152}$ but also in the specific context of repeat offender statutes, ${ }^{153}$ and its principles provide the most compelling reasons to include foreign convictions. Retribution theory focuses not on what is best for society or for the offender; instead, it bases the severity of punishment on the gravity of the act committed. ${ }^{154}$ Courts that have explicitly cited repeat offender statutes as retributive in nature consider a subsequent crime worse in and of itself than a first crime. ${ }^{155}$ Retribution theory does not contemplate punishing the first crime twice. Rather, a second offense, although possibly identical to the first in its outward conduct, deserves more punishment because its commission implies that the offender has not reformed despite being punished for the first one. ${ }^{156}$ Andrew von Hirsch, a "leading proponent[] of retribution," 157 has explained, "A repetition of the offense following [an earlier] conviction may be regarded as more culpable, since [the criminal] persisted in the behavior after having been forcefully censured for it . . .."158

A criminal should not be able to erase prior crimes by coming to the United States. In fact, the commission of a second crime in a second country warrants, if anything, more retribution than a second crime in the same country, because a person entering a new country has a chance to break free from old patterns and start anew. ${ }^{159}$ Thus, the commission of a crime in a second coun-

152. See supra text accompanying notes 139-41.

153. See supra text accompanying notes $142-48$.

154. ElLIS \& ELLIS, supra note 139 , at 2.

155. See supra text accompanying notes $142-48$.

156. The popular description of strict repeat offender statutes such as that in Washington, WASH. REv. CODE ANN. $\S$ 9.94A.120(4) (West Supp. 1994), captures this idea-"Three Strikes and You're Out." Gross, stipra note 3, at A1. In baseball, batters have less leeway with one or two strikes than with none. Swinging at a bad pitch with no strikes is like a misdemeanor but with two strikes is like a felony; the eventual strikeout, however, does not retroactively make the original strike any worse per se.

157. Schoellkopff, supra note 138, at 512 .

158. ANDREW VON HIRSCH, DÖING JUSTICE 85 (1976).

159. The United States, in particular, conveys this image. See Mark J. Estren, Take Pride in a Spanish Accent, and Learn to Communicate Well, MiAMI HERALD, Oct. 20, 1986, at 66B; Colin Nickerson, Some New Americans Enjoy Roast Turkey, Pie and Cha Gio Eggrolls, BOSTON GLOBE, Nov. 27, 1985, at A1. Some may advocate crediting a person with a clean slate upon entry into the United States, but the subsequent commission of a crime shows in retrospect that no such erasure of history was appropriate. See supra note 150 and accompanying text. 
try likely manifests individual fault rather than that of a particular environment. ${ }^{160}$

Furthermore, the failure to include foreign convictions as predicates for sentence enhancement ignores not only the policies behind such statutes, but also notions of equality. ${ }^{161}$ The primciple that like defendants should be treated alike is basic; ${ }^{162}$ the site of a previous crime is not a rational basis for distinguishing between two defendants whose conduct has been identical. ${ }^{163}$ Ironically, "[t] $\mathrm{t}$ he traditional skeptical attitude of Americans towards any criminal procedure other than that of the Anglo-Saxon system"164 disadvantages Americans sentenced as repeat offenders, compared to defendants who have committed previous crimes outside the country. The Washington Supreme Court, however, evinced a more cosmopolitan view in holding that a defendant's prior rape conviction in West Germany could be considered as a factor to justify sentencing the defendant to the maximum allowable term. ${ }^{165}$ Cutting through a haze of arguments about whether a judgment of the West German legal system should be respected, the trial court judge commented on the previous conviction, "That was a rape." 166 This judge recognized that the prior conduct of defendants in other countries is relevant to the discretionary deci-

160. Retribution theory measures punishment according to the immorality of an offense in light of its surrounding circumstances. For example, under this theory, a person who steals money to buy food for a starving child does not deserve as much punishment as one who steals money to buy a stereo. When the criminal history of a repeat offender has been limited to one country, the crimes can be attributed to external forces more easily than when the history is international; it is likely, if not beyond a reasonable doubt, that a criminal with an international criminal record deserves more retributive punishment. See supra note 150 and accompanying text.

161. Problems of unfairness in sentencing have long plagued American courts. See, e.g., Stephen J. Schulhofer, Due Process of Sentencing, 128 U. PA. L. REV. 733, 734 (1980); William W. Wilkins, Jr. et al., The Sentencing Reform Act of 1984: A Bold Approach to the Unwarranted Sentencing Disparity Problem, 2 CR1M. L.F. 355, 356 (1991).

162. Schoellkopff, supra note 138, at 504; see also 28 U.S.C. $\& 991(\mathrm{~b})(1)(B)$ (1988) (providing that defendants with similar records who have committed similar crimes should be similarly sentenced to avoid unwarranted disparities). The uneven sentencing of similarly situated defendants was one of the problems that spawned the Federal Sentencing Guidelines. Mistretta v. United States, 488 U.S. 361, 365 (1989); see also S. REP. No. 225, 98th Cong., 2d Sess. 44-46 (1984), reprinted in 1984 U.S.C.C.A.N. 3224, 3227-29 (citing a study in which judges given identical hypothetical case files handed down widely disparate sentences).

163. People v. Kearney, 258 N.Y.S.2d 769, 774-75 (Sup. Ct. 1965).

164. Pye, supra note 18 , at 115 .

165. State v. Herzog, 771 P.2d 739, 745 (Wash. 1989).

166. Id. at 740 . 
sions judges make when sentencing. ${ }^{167}$ The reprieve that judicial ignorance of this relevance grants to foreign criminals can lead to "invidious discrimination"168 against domestic criminals, which in turn harms the American public by precluding the attainment of the level of protection from repeat offenders that legislatures have deemed necessary.

\section{LIMITS ON THE USE OF FOREIGN CONVICTIONS}

The proposition that foreign convictions should be used to enhance penalties under repeat offender statutes does not suggest that they should escape scrutiny for fairness. Respect for foreign judgments should be extended only when warranted. Sister-state convictions may not be used if they are held to have been unconstitutionally obtained, ${ }^{169}$ and exempting foreign convictions from any type of due process analysis would discriminate against defendants with foreign convictions. ${ }^{170}$ The difficult issues are deciding to what extent the U.S. Constitution or the relevant state constitution applies and choosing a standard for providing protection where a constitution does not. The court in People $v$. Wallach ${ }^{171}$ summarized the principal concerns:

The problem of the use of evidence of foreign convictions involves a balancing of competing policy interests. On the one hand, we do not want to make use of evidence of convictions obtained in a system which is not fundamentally fair. On the other hand, we do not want miscreants to look upon Michigan as a sanctuary where their criminal activity in foreign countries can have no bearing on issues raised by new illegalities. ${ }^{172}$

Although it is debatable whether, as some commentators have claimed, "[t]he American people currently profess great faith in the criminal justice system," 173 it is likely that "[t]o Americans, steeped in a long and unique tradition of criminal-trial fairness,

167. Id. at 740-41. "[I]t would simply be unfair" to disfavor criminals whose prior criminality was confined to one geographical area. Hill v. State, 483 N.W.2d 57, 61 (Minn. 1992).

168. People v. Kearney, 258 N.Y.S.2d 769, 774 (Sup. Ct. 1965).

169. United States v. Tucker, 404 U.S. 443, 448 (1972).

170. See Kearney, 258 N.Y.S.2d at 773.

171. 312 N.W.2d 387 (Mich. Ct. App. 1981) (considering foreign conviction used to impeach a witness), vacated on other grounds, 331 N.W.2d 730 (Mich. 1983).

172. Id. at 403 .

173. Lee \& Searle-White, supra note 15 , at 32. 
the prospect of a foreign prosecution under less protective standards is disturbing." 174 However, "the erroneous belief that ours alone is a system which guarantees fairness to a criminal defendant" ${ }^{\prime 175}$ has led some courts to hold that foreign convictions never should be considered in sentencing. ${ }^{176}$ This view may be myopic, but certainly not all foreign judgments should be embraced. Reports have detailed incidences of physically tortured confessions in Mexican jails, ${ }^{177}$ for example, and United States courts have expressed outrage at injustices in the legal systems of several other countries. ${ }^{178}$

Courts have varied considerably in their approaches to evaluating the legal systems of foreign countries when deciding whether to respect foreign judgments; positions range from an absolute ban on foreign convictions ${ }^{179}$ to a lack of standards altogether. ${ }^{180}$

174. Holmes v. Laird, 459 F.2d 1211, 1223 (D.C. Cir.), cert. denied, 409 U.S. 869 (1972).

175. Gerhard O.W. Mueller, International Judicial Assistance in Criminal Matters, 7 VILL. L. REV. 193, 220 (1961-1962).

176. See, e.g., People v. Braithwaite, 240 N.W.2d 293, 294 (Mich. Ct. App. 1976) (holding that considering foreign convictions would be "manifestly unfair"); see also supra text accompanying notes 85-88.

177. U.S. Citizens Imprisoned in Mexico: Hearings on H.R. Res. 313 Before the Subcomm. on International, Political, and Military Affairs of the House Comm. on International Relations (Part II), 94th Cong., 2d Sess. 49 (1976) (statement of Hon. Leonard F. Walentynowicz, administrator, Bureau of Security and Consular Affairs, Department of State) (noting a pattern of deprivation of basic rights of American prisoners in Mexico); see also U.S. Citizens Imprisoned in Mexico: Hearings on H.R. Res. 313 Before the Subcomm. on International, Political, and Military Affairs of the House Comm. on International Relations (Part I), 94th Cong., 1st Sess. 5 (1975) (statement of Rep. Fortney H. Stark).

178. For example, a federal judge has decried the lack of "basic justice" in Iranian courts, noting that if the parties defending against a motion for forum non conveniens "returned to Iran to prosecute [their] claim, they would probably be shot." Rasoulzadeh v. Associated Press, 574 F. Supp. 854, 861 (S.D.N.Y. 1983), affd, 767 F.2d 908 (2d Cir. 1985); see also McDonnell Douglas Corp. v. Islamic Republic of Iran, 758 F.2d 341, 346 (8th Cir.) (observing that Americans are not treated fairly in Iranian courts), cert. denied, 474 U.S. 948 (1985). But see Cooley v. Weinberger, 518 F.2d 1151, 1155 (10th Cir. 1975) (recognizing the "legitimate legal process" of Iranian courts). A glance at the dates of these cases reveals that the revolution crippled justice in Iran, at least by American standards. One of the difficulties inherent in considering foreign convictions is that evaluations of the fairness of foreign legal systems must be updated continually to reflect political changes; making such judgments might strain courts' resources.

179. Braithwaite, 240 N.W.2d at 293.

180. Brice v. Pickett, 515 F.2d 153, 154 (9th Cir. 1975) (affirming deportation because of prior conviction of marijuana possession) ("Even if [petitioner] could prove that the [Japanese] conviction was obtained in proceedings which if conducted in this country would be violative of United States constitutional guarantees, we flnd no requirement 
The most popular method has been to apply constitutional procedural due process standards, just as courts do in evaluating sisterstate convictions as predicates for sentence enhancement. ${ }^{181}$

One problem with using traditional due process standards, though, is that the U.S. Constitution has a limited range of authority. Cases such as United States v. Verdugo-Urquidez, ${ }^{182}$ which held that the Fourth Amendment does not protect aliens outside the United States even when they are unwillingly subjected to the jurisdiction of United States courts, imply that defendants cannot claim due process protection in foreign courts. ${ }^{183}$ In other words, the U.S. Constitution cannot be "imposed" on foreign proceedings. ${ }^{184}$ In Reid $v$. Covert, however, the Supreme Court noted that citizens do not lose their rights by going abroad. ${ }^{185}$ Combined with Verdugo-Urquidez, this holding suggests that if both a citizen and an alien were tried in the United States under a repeat offender statute and each had prior, foreign convictions in the same country, only the citizen would benefit from the due process scrutiny of the legal system of the foreign country. This disparity would violate the principle of equality. ${ }^{186}$

A solution used by many courts is to restrict the reach of the Constitution and instead evaluate foreign convictions using a mythical universal standard of fairness. ${ }^{187}$ The Supreme Court has noted that "[f]ew would be so narrow or provincial as to maintain that a fair and enlightened system of justice would be impossible without [certain elements of American constitutional protec-

that a foreign court's proceedings or conviction must conform to United States constitutional standards.").

181. United States ex rel. Foreman v. Fay, 184 F. Supp. 535, 537, 539 n.15 (S.D.N.Y. 1960); People v. Kearney, 258 N.Y.S.2d 769, 772 (Sup. Ct. 1965); see also Pye, supra note 18 , at 129 ("A strict standard would nullify the effect of almost all foreign convictions obtained in civil law countries.").

182. 494 U.S. 259, 274-75 (1990).

183. See State v. Ford, 499 P.2d 699, 707 (Ariz. 1972) (noting that Americans leaving the country risk losing American procedural safeguards), cert. denied, 409 U.S. 1128 (1973).

184. Houle v. United States, 493 F.2d 915, 916 (5th Cir. 1974); see also People v. La Fargue, 195 Cal. Rptr. 438, 444 (Ct. App. 1983) (noting that foreign countries are not bound by U.S. Constitution).

185. 354 U.S. 1, 6 (1957).

186. See supra text accompanying notes $161-68$.

187. A difficulty with this approach is defining the universal standard. For a discussion of the variety of ways to express such a standard, see Frances T. Freeman Jalet, The Quest for the General Principles of Law Recognized by Civilized Nations-A Study, 10 UCLA L. REV. 1041 (1963). 
tion]." ${ }^{\prime 188}$ A federal court subsequently applied a test of fundamental fairness to a sentence that had been enhanced by a prior Mexican conviction, holding that "so long as there was ... fundamental [procedural] fairness, the Mexican conviction and sentence can be relied upon by this court for its sentence enhancement purposes." ${ }^{189}$ The application of a reasonable standard to appraise the procedural fairness of foreign convictions is an indispensable companion to the use of such convictions to enhance sentences. ${ }^{190}$

\section{A PROposed STANDARD}

Legislatures and courts in the United States should consider foreign convictions under repeat offender statutes. The decision to consider foreign convictions is only a starting point, however; the true effect accorded such convictions varies greatly with the type of limitations imposed to ensure fairness. The standard of "fundamental fairness" used by many courts misinterprets the issue; a "reliability of conviction" standard is more appropriate. To apply this standard, courts should inquire whether a foreign conviction is reliable evidence that indeed a crime did occur and whether the

188. Palko v. Connecticut, 302 U.S. 319, 325 (1937).

189. United States v. Moskovits, 784 F. Supp. 183, 189-90 (E.D. Pa. 1991) (noting that holding another country's courts to United States procedural standards would be "cultural imperialism" and holding that Mexican conviction did not pass the fairness test because counsel was not provided to defendant); see also People v. Wallach, 312 N.W.2d 387, 403 (Mich. Ct. App. 1981) (using standard of "fundamental fairness" to scrutinize foreign conviction to be used for impeachment), vacated on other grounds, 331 N.W.2d 730 (Mich. 1983).

190. One could argue that the United States interferes with other nations' sovereignty by giving effect to foreign convictions in its courts. See 2 BAssiounI \& NANDA, supra note $130, \S 6.2$, at $38-39$. The U.S. Supreme Court has held that "[a] sovereign nation has exclusive jurisdiction to punish offenses against its laws committed within its borders." Wilson v. Girard, 354 U.S. 524, 529 (1957). Although the concept of "sovereignty" is difficult to define, HURST HANNUM, AUTONOMY, SOVEREIGNTY, AND SELF-DETERMINATION 14 (1990), perhaps because it often is used in political rhetoric, ALAN JAMES, SovEREIGN STATEHOOD 1 (1986), basically it represents "the right of a state to freedom from foreign intervention in its internal affairs." JANKovIC, supra note 15, at 114; see also U.N. CHARTER art. 2, I 4 (protecting the "territorial integrity" of each nation). The question arises of whether the use of foreign offenses as predicates for enhanced sentences constitutes "punishing" the foreign offense. Recidivist statutes punish only the newest offense, not the predicate crimes. See supra text accompanying notes 145-46, 155-58. Therefore, recidivist statutes do not violate the sovereignty of other nations. In fact, the principle of comity among nations dictates respect for foreign judgments. State v. Meyer, 613 P.2d 132, 137 (Wash. Ct. App. 1980); see supra notes 81-82 and accompanying text. 
underlying conduct could be proscribed by an American state legislature and withstand a federal constitutional challenge.

The "fundamental fairness" and "reliability of conviction" standards overlap significantly. For example, a forced confession casts doubt on the determination of guilt at a trial, and a conviction based on such a confession would fail under both standards. Whereas the fundamental fairness approach is merely a diluted version of traditional procedural due process, however, the reliability of conviction standard is qualitatively different. Analysis under fundamental fairness excludes foreign convictions not only on the basis of injustices that cast doubt on the guilt of the defendant, but also on the basis of egregious conduct by a foreign government that is deemed to have violated a fundamental right of the defendant without placing the correctness of the verdict in doubt. ${ }^{191}$ The reliability of conviction standard, on the other hand, focuses only on whether the defendant actually engaged in the conduct constituting a crime in the foreign country, without regard to egregious governmental conduct per se. ${ }^{192}$

The reliability of conviction standard necessitates the application of a "hierarchy of rights" to determine which rights are so important that their violation casts doubt on the reliability of a conviction. ${ }^{193}$ The standard rests on the same principle the Burger Court often invoked in emphasizing the importance of truthfinding at trials: the criminal process should concentrate more on

191. For example, a verdict based on evidence that would have been suppressed under the exclusionary rule in the United States, Mapp v. Ohio, 367 U.S. 643 (1961), would not be in doubt.

192. An analysis of the law of entrapment illustrates the difference between the two standards. The subjective test that the Supreme Court has used focuses on the predisposition of a defendant to engage in the relevant criminal conduct rather than on the actions of government agents. Sherman v. United States, 356 U.S. 369, 373 (1958); Sorrells v. United States, 287 U.S. 435, 451 (1932). This idea is similar in its approach to the focus on the defendant of the reliability of conviction standard. The Supreme Court has hinted, however, at the possibility of a due process defense to government overinvolvement that would acquit even a predisposed defendant if the actions of the government were particularly censurable. United States v. Russell, 411 U.S. 423, 431-32 (1973). The Third Circuit upheld this defense in United States v. Twigg, 588 F.2d 373, 380-81 (3d Cir. 1978). The results of cases applying this defense are analogous to those using the fundamental fairness approach to foreign convictions, under which a defendant who actually engaged in the conduct underlying the conviction may receive somewhat of a reprieve from the violation of a personal constitutional right by the foreign government.

193. See Charles H. Whitebread, The Burger Court's Counter-Revolution in Criminal Procedure: The Recent Criminal Decisions of the United States Supreme Court, 24 WASHBURN L.J. 471, 471 (1985). 
separating the guilty from the innocent than on controlling official abuses of governmental power. ${ }^{194}$

Within the United States, it is conceivable that the controversial balance between the competing policies of convicting criminals and deterring egregious government conduct is properly struck; efforts to deter oppressive conduct of foreign governments, however, have hittle justification, so courts should focus solely on the reliability of conviction. The Arizona Supreme Court essentially reached this conclusion, noting that "[i]t is not the purpose of the rules in Mapp [v. Ohio] and Miranda [v. Arizona] to teach the Canadian police that their efforts will be wasted if they do not follow our basic laws. We have no extraterritorial jurisdiction even if that were our purpose."195

In addition to using the reliability of conviction standard, states should eliminate the requirement that foreign convictions constitute crimes in the American state in order to be counted. ${ }^{196}$ Conduct should be judged "by the prevailing norms in the jurisdiction where it was committed." 197 The principle of legality ${ }^{198}$ assumes, rightly or wrongly, that people are aware of laws. To some degree at least, people are influenced by legality and are less likely to engage in illegal conduct than in legal conduct, other factors being equal. ${ }^{199} \mathrm{~A}$ person who has committed a crime in another country has perhaps demonstrated not only the propensity to engage in the proscribed conduct but also an inherent disrespect for law. If this is the case, this person is likely to exhibit similar disrespect for the laws of the United States, even if the laws of the two countries are substantively different.

An extrapolation of the accepted doctrine, which focuses on the context of United States laws, illustrates its irrationality. If a

194. Stephen J. Schulhofer, The Constitution and the Police: Individual Rights and Law Enforcement, 66 WASH. U. L.Q. 11, 18 (1988).

195. State v. Ford, 499 P.2d 699, 706-07 (Ariz. 1972), cert. denied, 409 U.S. 1128 (1973). •

196. Some states do not have such a requirement for out-of-state prior convictions. See, e.g., McGirt v. State, 708 S.W.2d 620, 622 (Ark. 1986); State v. Taylor, 779 S.W.2d 636, 641 (Mo. Ct. App. 1989); Shannon v. State, 338 S.W.2d 462, 465 (Tex. Crim. App. 1960), cert. denied, 364 U.S. 935 (1961).

197. Pye, supra note 18, at 131; see also MODEL PENAL CODE $\S 7.05 \mathrm{cmt} .1$ (1962) (noting that time and place of previous conviction carry weight in determining gravity of offense).

198. See LAFAVE \& SCOTT (2d ed.), supra note 141, at 195.

199. See Tom R. Tyler, Why PeOple Obey the LAW 3 (1990). 
United States court finds that a defendant has engaged in conduct in a foreign country that was legal in the foreign country but is illegal in the United States, the accepted doctrine suggests that the court should treat this perfectly legal (within its context) conduct as a previous crime. This result is consistent with the nationality principle of international law, under which a country has jurisdiction over the conduct of its nationals even when they are out of the country. ${ }^{200}$ The United States, however, has not embraced this principle; ${ }^{201}$ to be consistent with this policy, American states should view foreign convictions in the proper context, respecting judgments regardless of the legality of the underlying conduct in the United States.

Limits are needed, however, as to which foreign crimes may be used to enhance sentences. The purpose of enhancing sentences is to punish people who deserve retribution in the judgment of American legislatures, not to punish people who have lived under regimes that prohibit what the United States considers protected conduct. The standard to screen out convictions under unreasonable foreign laws should be whether a statute using the same language as the foreign law would survive a constitutional challenge if enacted by an American state. This standard would leave enough foreign laws intact to identify blameworthy international criminals but would prevent people from receiving extra punishment if their foreign conduct has been above reproach from an American perspective. ${ }^{202}$

200. Nadelmann, supra note 14 , at 41 .

201. Id.

202. For example, a conviction under a foreign law proscribing newspapers critical of the government would not be counted in a prosecution under a repeat offender statute in the United States using this standard, because such a law would be struck as unconstitu. tional if a state passed it. On the contrary, a conviction for assault and battery under a foreign law criminalizing brawls among professional athletes at sporting events would be counted. Even though the foreign conduct would not be criminal in the United States, such a law could be enacted without violating the U.S. Constitution. Making determinations of this sort might strain the resources of courts, but the qualitative analysis would not differ from that involved in evaluating constitutional challenges to state laws. 


\section{CONCLUSION}

Justice Brennan criticized the imperialism of United States law in his dissent in United States v. Verdugo-Urquidez, ${ }^{203}$ noting that the country's "three largest exports are now 'rock music, blue jeans, and United States law.'" Legislatures and courts should continue to look abroad, but not to export American law; rather, they should extend the laws of other countries the respect they deserve by counting foreign convictions as predicates to enhance sentences when appropriate. Repeat offender statutes offer the opportunity for legislatures and courts to promote policy goals by expanding their often linited horizons. 